Preprint Of: Billett, D.S.M., Bett, B.J., Evans, R., Cross, I., Tyler, P.A., Wolff, G.A., 2013. The reproductive ecology of deep-sea ophiuroids around the Crozet plateau, Southern Indian ocean, under contrasting productivity regimes.

Deep-Sea Research II 92, 18-26.

\title{
The reproductive ecology of deep-sea ophiuroids around the Crozet Plateau, southern Indian Ocean, under contrasting productivity regimes
}

\author{
Billett, D.S.M. ${ }^{1}$, Bett, B.J. ${ }^{1}$, Evans, R. ${ }^{1}$, Cross, I. $^{1}$, Tyler, P.A. ${ }^{2}$ and Wolff, G.A. ${ }^{3}$ \\ 1. National Oceanography Centre, Southampton SO14 3ZH, UK \\ 2. Ocean and Earth Science, University of Southampton, National Oceanography Centre, Southampton, SO14 3ZH, UK \\ 3. Department of Earth and Ocean Sciences, University of Liverpool, Brownlow Street, Liverpool L69 3GP, UK. \\ *Corresponding author. Email: dsmb@noc.ac.uk. Tel: (+44) 2380596354
}

Keywords:

Ophiuroid,

Southern Indian

Ocean,

Crozet, reproductive

ecology, ocean productivity, benthos

\begin{abstract}
The reproductive characteristics of six ophiuroid species, Ophiura irrorata loveni, Ophiura lienosa, Amphioplus daleus, Ophiacantha cosmica, Ophiernus quadrispinus and Ophioplexa condita, were studied at two localities in the vicinity of the Crozet Islands in the Southern Indian Ocean. The two localities were notable in having almost identical environmental characteristics other than major differences in surface-water primary productivity and organic matter flux, whilst at the same time being only $460 \mathrm{~km}$ apart. Three species were sufficiently abundant at the two sites to compare their reproductive biology under different productivity regimes. Ophiura irrorata loveni showed significant differences in oocyte size distributions and population size distributions between the two sites which appeared to be related to the characteristics of organic matter flux at those localities. Ophiacantha cosmica and Ophioplexa condita showed differences in abundance between the two sites. This appeared to be related to the availability of suitable substrata.
\end{abstract}

\section{Introduction}

Variations in food supply to the seafloor in space and time are major drivers of change in deep-sea ecosystems. This is evident in many different localised ecosystems on the seafloor, such as hydrothermal vents, cold seeps, coral gardens and canyons. However, at abyssal depths, where large-scale environmental heterogeneity is generally less pronounced, the distributions of the vast majority of deep-sea fauna are dependent on variations in the flux of Particulate Organic Matter (POM) to the seafloor. Large-scale geographic differences in primary production at the sea surface and the subsequent export of carbon, drive variations in the place and pace of life on the deep-sea floor (Tyler et al. 1982; Billett et al. 1983; Tyler, 1996; Bett et al. 2001; Gooday 2002; Smith, C.R. et al. 2008; Smith, K.L. et al. 2009; Billett et al. 2010; Glover et al. 2010; Wei et al. 2010). Large-scale patterns in deep-sea communities (Sokolova, 2000; Ebbe et al. 2010) mirror surface water biogeochemical provinces (Longhurst, 2007) indicating that productivity is important in regulating the distributions of species. However, the relative importance of food supply, and whether all taxa respond in the same way, has been difficult to determine because environmental drivers change at different rates across regions and oceans. A solution is to study two closely situated localities with identical environmental characteristics, other than the amount of food supplied to the seabed.
In 2004 to 2006 a study was conducted at abyssal depths in the vicinity of the Crozet Islands in the Southern Indian Ocean (Wolff et al. 2011). The Crozet Islands lie within the large oceanic expanse of the Southern Hemisphere characterised by High Nutrient Low Chlorophyll (HNLC) waters. Primary productivity is limited by the availability of iron. However, in the vicinity of the Crozet Islands, and some other volcanic islands in the Southern Ocean, localised, intense and seasonal blooms of primary production occur, stimulated by natural iron fertilisation derived from the islands (Blain et al. 2007; Pollard et al. 2007a, 2009). At Crozet, the regional oceanic circulation restricts the iron to an area north and east of islands, providing a strong contrast, in terms of productivity, to HNLC waters to the south and west of the archipelago (Figure 1A). The setting allows localities to be compared under different productivity regimes, but in close proximity. Wolff et al. (2011) selected two areas which balanced the competing demands of 1) generating the greatest contrast in productivity regime and 2) maintaining the greatest similarity in all other environmental variables. Two sites at abyssal depths were chosen (Hughes et al. 2009) (Figure 1A,B). One was influenced by iron fertilisation $(+\mathrm{Fe})$ and the other was located just $460 \mathrm{~km}$ distant but in low iron, HNLC waters. The two sites were at the same depth, in the same water mass and there was no topographic barrier between them. They differed only in total POM flux and in the intensity, and potentially the regularity, of seasonal inputs (Wolff et al. 2011; Salter et al. 2012). 
Three cruises were conducted to the remote Crozet region, two spanning the period November 2004 to January 2005, and a third from December 2005 to January 2006. The first two cruises were dedicated to upper ocean biogeochemistry and a small amount of sediment coring. No trawling was possible. The third cruise was dedicated to benthic sampling, but also undertook work on water column biogeochemistry, including the recovery of a number of sediment trap moorings that had been deployed on the first two cruises (Pollard et al. 2007a; Wolff et al. 2011).

Holothurians dominated the benthic trawl samples and showed significant differences between the two productivity regimes (Wolff et al. 2011). There was a greater similarity in the gross composition of the $+\mathrm{Fe}$ holothurian fauna with abyssal communities in eutrophic waters of the NE Atlantic, 16,000 km distant, than with the closely situated HNLC site. In addition, the most abundant species at Crozet, the holothurian Peniagone crozeti (Cross et al. 2010) was new to science and occurred almost exclusively at the $+\mathrm{Fe}$ site (Wolff et al. 2011). The results indicated that productivity was of prime importance in regulating the distributions of abyssal holothurians.

Other notable echinoderm taxa at Crozet were the Asteroidea and Ophiuroidea (Wolff et al. 2011). The asteroids accounted for 3 and $6 \%$ of megafaunal abundance, and 3 and $20 \%$ of wet weight biomass, at the $+\mathrm{Fe}$ and HNLC sites, respectively. Similarly the ophiuroids comprised 3 and $7 \%$ of the wet weight biomass at $+\mathrm{Fe}$ and HNLC. However, in contrast to the asteroids, the ophiuroids were exceptionally numerous and accounted for between 36 and $43 \%$ of the individuals collected at the two sites. Ophiuroids clearly play an important role in ecosystem functioning in the region. This paper focuses on the abyssal ophiuroids at Crozet. It provides details of the reproductive biology of the dominant species, including comparing the species at the $+\mathrm{Fe}$ and HNLC sites.

Reproduction in deep-sea echinoderms has been shown to be coupled closely with the flux of organic matter to the deep-sea floor (Tyler et al. 1982; Tyler, 1988). However, despite the diversity and abundance of ophiuroids in many deep-sea habitats (Tyler 1980; Gage and Tyler 1991) the reproductive biology and mode of larval development of the majority of species are not known. Generally, deep-sea ophiuroids exhibit asynchronous reproduction (Young, 2003) although episodic recruitment may occur in some species, such as Ophiomusium lymani (Gage, 1982; Gage \& Tyler, 1982). A few species reproduce seasonally, including Ophiura ljungmani, Ophiocten gracilis and Ophiocten hastatum (Tyler and Gage 1980; Sumida et al. 2000; Gage et al. 2004). The Rockall Trough time series was instrumental in determining periodicity in reproduction and recruitment of deep-sea ophiuroids (Gage et al. 1980).
While this paper sampled only at one time point at Crozet, owing to the logistics of working in such a remote region, it is the first study to sample concurrently two localities in close proximity, but under different productivity regimes, and to compare species common to both areas.

\section{Materials and Methods}

\section{The Study Area}

The Crozet Islands (Crozet) are located in the Polar Frontal Zone at the northern boundary of the Southern Ocean (Pollard et al. 2009). The Antarctic Circumpolar Current (ACC) flows eastwardly in this part of the Southern Ocean. Owing to a semi-permanent meander in the Sub-Antarctic Front, a 'hotspot' of iron-induced seasonal productivity is created in, and restricted to, an area to the north and east of Crozet (Pollard et al. 2007b; Wolff et al. 2011). To the south of Crozet, HNLC conditions prevail (Pollard et al. 2007a: Wolff et al. 2011, Figure 1A). SeaWIFS images confirm that every year during the austral summer high levels of primary productivity occur only to the north and east of Crozet (Venables et al. 2007; Pollard et al. 2009). The differences in productivity have probably persisted for a very long time (at least thousands of years).

The two sites at Crozet used in this study were chosen to determine the influence of productivity on the distributions and ecology of deep-sea megafauna (Figure 1A,B). The two sites, situated $460 \mathrm{~km}$ apart, were at the same water depth $(\sim 4200 \mathrm{~m})$ and were almost identical in their geomorphological, hydrographical and sedimentary characteristics (Wolff et al. 2011). There was no physical barrier between the two localities (Hughes et al. 2007) ensuring connectivity, other than barriers imposed by differences in productivity and biogeochemistry.

The biogeochemistry of the upper water column surrounding Crozet was studied during the austral summers of 2004/05 (Blain et al. 2007; Pollard et al. 2009). Sediment trap moorings deployed at the two sites showed distinct differences with greater, and longerlasting, particulate flux at the $+\mathrm{Fe}$ site (Salter et al. 2012). The organic carbon flux at the $+\mathrm{Fe}$ site was about three times greater than at the HNLC site $(41.1 \mathrm{mmol}$ $\mathrm{m}^{-2}$ and $14.1 \mathrm{mmol} \mathrm{m}^{-2}$ over 355 and 352 , respectively) (Wolff et al. 2011 Figure 2; Salter et al. 2012). Additionally, the chemical composition of the particulate material at the $+\mathrm{Fe}$ site was of a better quality, with greater concentrations of labile lipids, polyunsaturated fatty acids (PUFAs) and monounsaturated fatty acids (MUFAs) (Wolff et al. 2011). PUFAs were below detection limits at the HNLC site.

The biomass and abundance of benthic invertebrate megafauna in total was greater at the $+\mathrm{Fe}$ site than the HNLC site by factors of three and six respectively (Wolff et al. 2011). 


\section{Sampling details}

Ophiuroids were collected by single warp, semi-balloon otter trawl from two localities a) $+\mathrm{Fe}$ (Station 15773) and b) HNLC (Station 15775) (Figure 1A,B; Table 1). Four trawls were taken at the $+\mathrm{Fe}$ site. However, owing to the loss of the trawl and $8000 \mathrm{~m}$ of wire, only two trawls were possible at the HNLC site. Specimens were fixed in $10 \%$ formalin and then transferred to $80 \%$ ethanol for storage. The samples were archived in the Discovery Collections at the National Oceanography Centre, Southampton, UK.

The reproductive biology of the six most abundant ophiuroid species was analysed: Ophiura irrorata loveni (Lyman 1878), Ophiura lienosa (Lyman 1878), Amphioplus daleus (Lyman 1879), Ophiacantha cosmica Lyman 1878, Ophiernus quadrispinus Koehler 1908 and Ophioplexa condita Martynov, 2010. Three other species, Amphioplus antarctica, Amphiura studeri (antarctica) (Lyman) and Ophiolepis scissa, also occurred at Crozet, but in much smaller numbers and were not studied, except for details of their abundances and biomass.

\section{Population size distributions}

The preserved wet weight $(\mathrm{g})$ and disc radius $(\mathrm{mm})$ were measured for each individual. The samples were all taken in the austral summer of December 2005 to January 2006.

\section{Reproductive biology}

Three species were sufficiently numerous at both the $+\mathrm{Fe}$ and HNLC sites for their reproductive biology to be compared histologically: Ophiura irrorata loveni, Ophiura lienosa and Amphioplus daleus. Two species, Ophiacantha cosmica and Ophioplexa condita, were abundant only at the HNLC site in sufficient quantity for their reproductive biology to be analysed. Similarly, Ophiernus quadrispinus occurred only at the $+\mathrm{Fe}$ site. Many of the specimens had been damaged in the trawl. Only individuals with an intact disc were used for the reproduction analyses.

A total of 160 individuals were sectioned. The sex of each individual was determined from gonad morphology. No hermaphrodites were present. Gonads were processed to paraffin wax, sectioned at $7 \mu \mathrm{m}$ then stained with Haematoxylin ' $Z$ ' and counterstained in Eosin (Cellpath UK). The oocyte feret diameters $(\mu \mathrm{m})$ of at least 100 oocytes were measured from each female using the imaging software SigmaScan Pro4 (Jandell Scientific Software). Feret diameter is an estimate of an oocyte diameter assuming the best-fit to a perfect spherical shape for the oocyte. Only oocyte sections possessing a nucleus were measured. To compare differences in oocyte sizes between the two productivity regimes, the data were grouped into $20 \mu \mathrm{m}$ size classes.

\section{Statistical analyses}

Statistical analyses were used to compare data within, and between, sites. An analysis of variance (ANOVA) was conducted on $\log (\mathrm{x}+1)$ transformed abundance and biomass data to compare the $+\mathrm{Fe}$ and HNLC sites. A
Mann-Whitney Rank Sum Test was used to test the differences in the distribution of disc sizes between the $+\mathrm{Fe}$ and HNLC sites. A chi-square test for homogeneity was also used to test the hypothesis that no samples deviated from a 1:1 sex ratio. A Kruskal-Wallis and Dunn Pairwise comparison test was carried out to determine whether there was a significant difference in oocyte size between sites (Siegel \& Castellan, 1988; Sokal \& Rohlf 1995).

\section{Results}

\section{Abundance and biomass}

The mean abundance of ophiuroids in total was greater at the $+\mathrm{Fe}$ site $\left(484 \pm 319\right.$ ind $\left.^{-1} \mathrm{ha}^{-1}\right)$ than at the HNLC site $\left(332 \pm 121\right.$ ind. ha $\left.^{-1}\right)$. There was great variability between samples at each site (Table 2). No significant differences could be detected. The mean wet weight biomass was greater at the $+\mathrm{Fe}$ site $\left(162 \pm 86 \mathrm{~g} \mathrm{ha}^{-1}\right)$. There was no significant difference from the HNLC site $\left(121 \pm 48 \mathrm{~g} \mathrm{ha}^{-1}\right)$ (Table 2).

Ophiura lienosa was the dominant ophiuroid species at both sites (Table 2; Figures 2A,B; 3A,B). While $O$. lienosa was slightly more common at the productive + Fe site, there was no significant difference between the two sites. Similarly, Ophiura irrorata loveni was more common at the $+\mathrm{Fe}$ site, but not significantly. Amphioplus daleus showed a similar trend, but more marked. While there was no significant difference in abundance, biomass was significantly greater at the $+\mathrm{Fe}$ site $(\mathrm{p}<0.02) \quad$ (Table 2; Figure 2B). Ophiacantha cosmica was proportionally more abundant at the HNLC site than at the +Fe site $(10 \%$ and $2 \%$ respectively) and Ophioplexa condita occurred almost exclusively at the HNLC site, with highly significant differences for both abundance $(\mathrm{p}<0.0001)$ and biomass $(p<0.005) \quad$ (Table 2, Figures 2A,B). The relative abundance of the ophiuroid species and the overall composition of the ophiuroid community were similar for all samples within each site. However, the composition of the ophiuroid biomass showed differences between the two sites, particularly for the minor species (Figures 3A,B).

\section{Population size distributions}

Population size distributions were obtained for each species from a broad range of sample sizes $(\mathrm{N}=17$ to 2386 individuals, depending on the species). The disc radius of Ophiura irrorata loveni ranged from 2 to 17 $\mathrm{mm}$. The size distribution at $+\mathrm{Fe}$ was unimodal, skewed toward larger disc sizes and with a median disc size of $12 \mathrm{~mm}$ (Figure 4A). In contrast, the population size distribution at the HNLC site was bimodal, with a greater proportion of small individuals. The two modes had median disc radii of 5 and $14 \mathrm{~mm}$. The population size distributions were significantly different $(\mathrm{p}<0.001)$. The dynamics of recruitment of $O$. irrorata loveni were different at the $+\mathrm{Fe}$ and $\mathrm{HNLC}$ sites.

The specimens of Ophiura lienosa were generally much smaller than $O$. irrorata loveni and of a size that may not have been collected effectively by the otter trawl. 
The disc radii of all but one specimen ranged between 1 and $8 \mathrm{~mm}$. The median disc radius of $5 \mathrm{~mm}$ was similar at the $+\mathrm{Fe}$ and HNLC sites, but there was a significantly different number of smaller individuals at the $+\mathrm{Fe}$ site $(\mathrm{p}<0.001)$ (Figure 4B). Amphioplus daleus showed the reverse trend with significantly smaller individuals at the HNLC site $(\mathrm{p}<0.001)$ (Figure 4C). The median disc radius at the HNLC site was $5 \mathrm{~mm}$ as opposed to $6 \mathrm{~mm}$ at the $+\mathrm{Fe}$ site.

The disc radius of Ophiacantha cosmica ranged from 2 to $11 \mathrm{~mm}$. The population size distributions at both sites showed evidence of two modes occurring at similar disc radii with median values of 3 and $7 \mathrm{~mm}$ for each mode (Figure 4D). There was no significant difference in the two size distributions.

The sample size of Ophiernus quadrispinus was very small at the HNLC site $(\mathrm{N}=17)$. The individuals were slightly smaller at the $+\mathrm{Fe}$ site but not significantly (Figure 4E). Ophioplexa condita occurred only at the HNLC site. Disc radii ranged from 2 to $7 \mathrm{~mm}$ (Figure 4F).

Reproductive biology: sex ratios and oocyte sizefrequency distributions

One hundred and sixty individuals were examined histologically; $45 \%$ were female and $55 \%$ male. There was no significant deviation from the expected 1:1 sex ratio for any of the species. Histological sections showed two types of oocytes; previtellogenic oocytes recognised by their small size, and vitellogenic oocytes characterised by their larger and coarser appearance with an eosinophilic cytoplasm (Hendler 1991; Grange et al. 2004).

Ophiura irrorata loveni, Ophiura lienosa, Amphioplus daleus and Ophiacantha cosmica showed a wide range of oocyte sizes at both the $+\mathrm{Fe}$ and the HNLC sites (Figure 5A-C). The median oocyte size Ophiura irrorata at the $+\mathrm{Fe}$ site $(40-60 \mu \mathrm{m})$ was much smaller than at the HNLC site (160-180 $\mu \mathrm{m})$. Maximum egg size was greater at the HNLC site $(400 \mu \mathrm{m})$ than at the + Fe site $(320 \mu \mathrm{m})$. The egg size distributions were significantly different (ANOSIM $\mathrm{p}<0.001$ ) (Figure 5A). There was a preponderance of small previtellogenic eggs at the $+\mathrm{Fe}$ site which may have indicated a spawning event in the austral spring prior to sampling.

No significant differences were found in oocyte sizes for any of the other species. Ophiura lienosa had a median egg size of 40-60 $\mu \mathrm{m}$ (Figure 5B). Maximum egg size was slightly larger at the $+\mathrm{Fe}$ site $(380 \mu \mathrm{m})$ than at the HNLC site $(340 \mu \mathrm{m})$. The vast majority of eggs were very small and at the previtellogenic stage at both the $+\mathrm{Fe}$ and HNLC sites. Amphioplus daleus also had similar oocyte sizes at the $+\mathrm{Fe}$ and HNLC sites, but in this case there were very few previtellogenic oocytes and the eggs ranged over a broad size range between 80 and $200 \mu \mathrm{m}$ (Figure 5C). Ophiernus quadrispinus (at the $+\mathrm{Fe}$ site) and Ophioplexa condita (at the HNLC site) had oocyte size distributions skewed to small previtellogenic egg sizes (Figure 5E,F). Only three females of Ophioplexa condita were analysed. In one specimen all the eggs were less than $100 \mu \mathrm{m}$ in diameter.

Individuals of Ophiacantha cosmica sampled under HNLC conditions exhibited a wide range in oocyte diameter, from 30 to $560 \mu \mathrm{m}$, although the vast majority of the eggs were only 40 to $140 \mu \mathrm{m}$ (Figure 5D). Seven of the eleven females examined contained oocytes with diameters greater than $400 \mu \mathrm{m}$ indicating lecithotrophic development.

\section{Discussion}

The Crozet abyssal ophiuroids had maximum egg sizes between 200 and $550 \mu \mathrm{m}$ (Figure 4A-F) indicating lecithotrophic or direct development in the different species. Three species, Ophiura irrorata loveni, Ophiura lienosa and Amphioplus daleus, were sampled in two different productivity regimes (+Fe and HNLC) allowing their reproductive biology to be compared in relation to food supply to the deep-sea benthos. Of these species, there was a significant difference in the oocyte size distributions of $O$. irrorata loveni between $+\mathrm{Fe}$ and HNLC, but not for O. lienosa or A. daleus. The latter two species, however, differed in their egg size distributions. This indicates that the two species had different reproductive characteristics despite having a similar maximum egg size. All species showed 1:1 sex ratios.

\section{Ophiura irrorata loveni}

The oocyte distributions of $O$. irrorata loveni were significantly different between the $+\mathrm{Fe}$ and HNLC sites (Figure 5A). At the productive $+\mathrm{Fe}$ site, the egg size distribution was skewed to small previtellogenic eggs ( $50 \%$ of the eggs were smaller than $80 \mu \mathrm{m}$ ). There was some variation between individuals at both sites (Figure 6A,B). Highly significant differences were evident also in the population size distributions. While a unimodal size distribution occurred at $+\mathrm{Fe}$, the HNLC site had a distinct bimodal size distribution (Figure 4A).

The differences noted in the oocyte and population size distributions may have been related to the dynamics of POC flux at each locality. At $+\mathrm{Fe}$ the total flux recorded by sediment traps was 2.4 times greater than at HNLC (Wolff et al. 2011; Salter 2012). In addition, the period over which the flux of POM occurred extended over c. 150 days at $+\mathrm{Fe}$, as opposed to just 14 days at HNLC. Satellite images of ocean colour at Crozet show that for most years HNLC conditions prevail to the south of the islands. Occasionally, though, mesoscale eddies spin off from the Crozet Plateau to the south in some years (Pollard et al. 2007a). These eddies may lead to sporadic, short and intense POM fluxes to the seabed, as seen in early 2005 (Wolff et al. 2011; Salter et al. 2012). No POM flux event was evident in the sediment trap record at the HNLC site before the traps were recovered in early January 2006 (i.e. before the end of the austral summer). Based on the satellite and sediment trap data, sporadic, inter-annual variations in POM flux would appear to be a feature of the productivity regime south 
of the Crozet Islands. This hypothesis is supported by the presence at the HNLC site of small opportunistic holothurians, notably Kolga nana, in January 2006 (Wolff et al. 2011). Dense aggregations of Kolga are considered to be indicative of intermittent flux events (Billett \& Hansen, 1982). Similarly, episodic recruitment of ophiuroids is known to occur in response to intermittent POM flux events at other abyssal localities in the world's oceans (Gage et al 2004; Booth et al. 2008).

While sporadic (inter-annual) and patchy POM inputs are thought to occur at the HNLC site, a different productivity and export flux regime characterised the + Fe site. Here, regular seasonal POM fluxes occur, although, as in seasonal eutrophic waters of the NE Atlantic (Lampitt et al. 2010), the intensity of the POM flux may vary from year to year. The greater flux of organic matter to the seafloor at $+\mathrm{Fe}$ also led to a greater benthic biomass and abundance of megafauna at this locality. Benthic biomass at $+\mathrm{Fe}$ was three times greater than at HNLC.

The greater proportion of pre-vitellogenic eggs in $O$. irrorata loveni at $+\mathrm{Fe}$ (Figure $5 \mathrm{~A}$ ) is indicative of a recent spawning event in the austral spring and early summer, presumably in response to the regular seasonal input of POM (Wolff et al. 2011). In contrast, no new POM flux was evident in January 2006 at the HNLC site and, consequently, spawning appears to have been deferred, leading to a greater proportion of large eggs (Figure 5A). At HNLC, O. irrorata loveni exhibits a more continuous, asynchronous investment in reproduction, which might be advantageous in habitats where food supplies are irregular and limited (Tyler and Gage 1982; Lauermann \& Kauffmann 1998).

Apart from the differences in oocyte distributions, a disparity was evident also in the population size distributions of $O$. irrorata loveni. At HNLC a bimodal population size distribution occurred in January 2006 (Figure 4A). This may reflect greater recruitment in response to the intense, but short, POM flux at the HNLC site in January 2005 (Wolff et al. 2011; Salter et al. 2012). The limited benthic biomass at HNLC would lead to reduced predation on post larval ophiuroids allowing a distinct cohort of recent recruits to appear the following year, January 2006 when the benthic sampling took place. A similar recruitment event, however, was not evident at the $+\mathrm{Fe}$ locality, even though the oocyte size distribution indicated possible seasonal changes in spawning intensity. The lack of a distinct cohort of smaller individuals at $+\mathrm{Fe}$ may have been due to the greater biomass and abundance of megafauna and hence greater predation pressure at this locality (Wolff et al. 2011).

A link between food availability and reproductive periodicity has been noted in many deep-sea ophiuroids, including 1) seasonal responses (Schoener, 1972; Tyler \& Gage 1980; Tyler et al. 1982) and 2) longer term variations related to climate oscillations (Booth et al. 2008). The diet of $O$. irrorata is extremely variable. It consumes detritus but also a wide variety of small invertebrates and even small fish, particularly when detritus is scarce on the seafloor (Pearson and Gage 1984). The broad diet of $O$. irrorata allows continuous investment in reproduction throughout the year, although greater spawning may be stimulated by seasonal and episodic inputs of detritus.

\section{Ophiura lienosa and Amphioplus daleus}

In contrast to O. irrorata loveni, the species Ophiura lienosa and Amphioplus daleus showed no significant differences in their oocyte size distributions between the $+\mathrm{Fe}$ and HNLC localities (Figure 5B,C). Egg size distributions for $O$. lienosa were skewed to small previtellogenic oocytes at both sites (56 to $66 \%$ were smaller than $80 \mu \mathrm{m}$ at $\mathrm{HNLC}$ and $+\mathrm{Fe}$ sites respectively; Figure $5 \mathrm{~B}$ ). In contrast, only $10 \%$ of the eggs in $A$. daleus were smaller than $80 \mu \mathrm{m}$, at both sites, and most eggs had a diameter between 100 and $200 \mu \mathrm{m}$. The reasons for the different egg size distributions for two species despite having similar maximum egg sizes are not immediately obvious.

\section{Ophiacantha cosmica}

The largest egg size in Ophiacantha cosmica (Figure 5D), $550 \mu \mathrm{m}$, was of a similar size to that recorded for Ophiacantha bidentata (650 $\mu \mathrm{m}$, Tyler \& Gage 1982), a protandric hermaphrodite. In $O$. bidentata ovotestes occurred in individuals with a disc diameter of 4 to 9 $\mathrm{mm}$, while specimens larger than $9 \mathrm{~mm}$ had only ovaries. Ophiacantha bidentata had a bimodal population size distribution (Tyler \& Gage 1982). Histological observations showed that the two population size modes represented different stages of reproductive development. Smaller individuals had ovotestes with spermatozoa and moderately sized eggs. Larger individuals had just large eggs. Ophiacantha cosmica showed a similar bimodal population size distribution. However, males and females were separate in all size classes and there was no evidence of ovotestes in smaller individuals. The bimodal distribution in O.cosmica, therefore, does not appear to be related to differences in reproductive development.

Ophiacantha cosmica was more prevalent at the HNLC site (Figure 3). Ophiacantha cosmica is a suspension feeder differing in its feeding habits to the other species at Crozet. Species of Ophiacantha have an epifaunal habit and are often found associated with hard rock substrata and deep-water corals (Tyler 1980). The HNLC site was notable for a greater number of worm tubes and cnidarians (Wolff 2006; Wolff et al. 2011). The increased abundance of $O$. cosmica at HNLC therefore was more likely to be related to the greater number of suitable substrates, rather than to reproductive processes.

\section{Ophioplexa condita and Ophiernus quadrispinus}

Ophioplexa condita and Ophiernus quadrispinus had apparent maximum egg sizes of between 200 and 250 $\mu \mathrm{m}$, indicative of lecithotrophic development. The egg size distributions were similar to other ophiuroid species known to have asynchronous continuous development. 
Population size distributions in these species were unimodal. There was an indication of smaller individuals occurring at the $+\mathrm{Fe}$ site for Ophiernus quadrispinus, but this apparent difference may have been due to the small sample size (17 individuals) at the HNLC site. No significant difference was evident between the two distributions for $O$. quadrispinus at $+\mathrm{Fe}$ and HNLC.

Ophioplexa condita has numerous spinelets on its arms and therefore is likely to be a suspension feeder. As for Ophiacantha cosmica, the prevalence of $O$. condita almost exclusively at the HNLC site (Figure 2A,B) is likely to be related to the availability of worm tubes and cnidarians to cling to, rather than reproductive processes.

\section{Overview}

The high abundance of ophiuroids at the $+\mathrm{Fe}$ and HNLC localities sampled at Crozet (36 to $43 \%$ of the individuals collected at each locality) indicates that ophiuroids are significant component of the abyssal benthos in this region. However, unlike the other dominant benthic taxa at Crozet which showed very significant differences in species at the $+\mathrm{Fe}$ and HNLC sites (Wolff et al. 2011), the dominant ophiuroid species were, by comparison, remarkably constant. The differences evident in the wider megabenthos taxa, especially the holothurians, and attributed by Wolff et al. (2011) to dissimilarities in POM flux and food supply, would appear to be less important to ophiuroid species.

This may be related to the varied diet of many ophiuroids (Tyler, 1980; Warner, 1982; Pearson \& Gage, 1984). While overall ophiuroid biomass may reflect total POM flux to the seabed, the ophiuroid species present are less dependent than other deep-sea taxa on the dynamics of the POM regime. However, this is not necessarily true of all abyssal ophiuroid species. In the NE Atlantic Ophiocten hastatum has been shown to have an isotopic composition indicative of feeding on fresh phytodetritus (Iken et al. 2001) and to change radically in its abundance in response to changes in POC flux (Bett et al. 2001; Gage et al. 2004).

Ophiura irrorata loveni has a similar disc size and population size distribution to O. bathybia (Booth et al. 2008) in the NE Pacific. The two species may play similar ecological roles and respond to environmental change in a similar way. Time series studies of $O$. bathybia have shown inter-annual variation in size distributions with a lagged relationship to POM flux (Booth et al. 2008). Increases in POM flux were followed 17 to 22 months later by increases in smaller size classes of $O$. bathybia. Unlike holothurians, which feed directly on labile phytodetritus (Wigham et al. 2003) and which may change suddenly in abundance (Billett et al. 2001, 2010; Ruhl, 2007; Smith et al. 2009), O. bathybia had a longer reaction time. This may reflect the less responsive characteristics of the reproductive biology of the ophiuroids, or may be related to time-lagged responses of their food, principally macrofauna, to POM flux. Macrofauna have been shown to change in biomass relative to changes in POC input (Soto et al. 2010) which may lead to longerphase changes in ophiuroid biomass and abundance.

\section{Acknowledgements}

We thank Alexander Martynov and Tim O'Hara for their help in the identifications of the ophiuroid species and for advice on the taxonomy of the Ophiuroidea. We are grateful to the Master, Officers and Crew of the RRS Discovery, and all the technical and scientific staff on board RRS Discovery Cruise 300 for their assistance at sea. The project contributed to the Census of the Diversity of Abyssal Marine Life (CeDAMar), a field project of the Census of Marine Life (CoML). Financial support for the work was provided by the Natural Environment Research Council (NERC) Research Grant NER/A/S/2003/00576 and the Ocean Biogeochemistry and Ecosystems (OBE) Group, National Oceanography Centre, Southampton.

\section{References}

Bett, B.J., Malzone, M.G., Narayanaswamy, B.E., Wigham, B.D., 2001. Temporal variability in phytodetritus and megabenthic activity at the seabed in the deep Northeast Atlantic. Progress in Oceanography 50, 349-368.

Billett, D.S.M., Hansen, B., 1982. Abyssal aggregations of Kolga hyalina Danielssen and Koren (Echinodermata: Holothurioidea) in the northeast Atlantic Ocean: a preliminary report. Deep-Sea Research 29, 799-818.

Billett, D.S.M., Lampitt, R.S., Rice, A.L., Mantoura, R.F.C., 1983. Seasonal sedimentation of phytoplankton to the deep-sea benthos. Nature 302, 520-522.

Billett, D.S.M., Bett, B.J., Rice, A.L., Thurston, M.H., Galéron, J., Sibuet, M., Wolff, G.A., 2001. Long-term change in the megabenthos of the Porcupine Abyssal Plain (NE Atlantic). Progress in Oceanography 50, 325-348

Billett, D.S.M., Bett, B.J., Reid, W.K.D., Boorman, B., Priede, I.M., 2010. Long-term change in the abyssal NE Atlantic: The 'Amperima Event' revisited. Deep-Sea Research II 57 (15), 14061417.

Blain, S., Quéguiner, B., Armand, L., Belviso, S., Bombled, B., Bopp, L., et al., 2007. Effect of natural iron fertilization on carbon sequestration in the Southern Ocean. Nature 446, 1070-1071.

Booth, J.A.T., Ruhl, H.A., Lovell, L.L., Bailey, D.M., Smith, K.L. Jr., 2008. Size-frequency dynamics of NE Pacific abyssal ophiuroids (Echinodermata: Ophiuroidea). Marine Biology 154, 933-941.

Cross, I.A., Gebruk, A., Billett, D.S.M., Rogacheva, A., 2009. Peniagone crozeti, a new species of elasipodid holothurian from abyssal depths off the Crozet Isles in the Southern Indian Ocean. Zootaxa 2096, 484-488.

Ebbe, B., Billett, D.S.M., Brandt, A., Ellingsen, K., Glover, A., Keller, S., Malyutina, M., Martinez, P., Molodtsowa, T., Rex, M., Smith, C.R., Tselepides, T., 2010. Diversity of Abyssal Marine Life. In: McIntyre, A., (Ed). Chapter 8. Life in the World's Oceans: Diversity, Distribution and Abundance. Wiley-Blackwell. 139160.

Gage, J.D. 1982. Age structure in populations of the deep-sea brittle star Ophiomusium lymani: a regional comparison. Deep-Sea Research 29A, 1505-1586.

Gage J.D., Tyler, P.A., 1982. Growth and reproduction of the deep-sea brittlestar Ophiomusium lymani Wyville Thomson. Oceanologica Acta 5, 73-83.

Gage J.D., Tyler, P.A., 1991. Deep-Sea Biology: A natural history of organisms at the deep-sea floor. Cambridge University Press. 504pp.

Gage J.D., Lightfoot, R.H., Pearson, M., Tyler, P.A., 1980. An introduction to a time series of abyssal macrobenthos: methods and principal sources of variability. Oceanologica Acta 3, 169176.

Gage, J.D., Anderson, R.M., Tyler, P.A. Chapman, R, Dolan, E, Sibuet, M., Galéron, J., 2004. Growth and reproduction in the 
abyssal brittle star Ophiocten hastatum (Ophiuroidea: Echinodermata) in the NE Atlantic, and the 'Amperima event'. Deep-Sea Research I 51, 849-864.

Glover, A G, Gooday, A.J., Bailey, D.M., Billett, D.S.M., Chevaldonné, P., et al., 2010. Temporal change in deep-sea benthic ecosystems: A review of the evidence from recent time series studies. Advances in Marine Biology 58, 1-95.

Gooday, A.J., 2002. Biological responses to seasonally varying fluxes of organic matter to the ocean floor: A review. Journal of Oceanography 58, 305-332.

Hughes, J.A., Smith, T., Chaillan, F., Bett, B.J., Billett, D.S.M., Boorman, B., Fisher, E.H., Frenz, M., Wolff, G.A., 2007. Two abyssal sites in the Southern Ocean influenced by different organic matter inputs: Environmental characterization and preliminary observations on the benthic foraminifera. Deep-Sea Research II 54, 2275-2290.

Iken, K., Brey, T., Wand, U., Voigt, J. Junghans, P., 2001. Food web structure of the benthic community at the Porcupine Abyssal Plain (NE Atlantic): a stable isotope analysis. Progress in Oceanography 50, 383-405.

Lampitt, R.S., Salter, I., de Cuevas, B., Hartman, S., Larkin, K.E., Pebody, C.A., 2010. Long-term variability of downward particle flux in the deep northeast Atlantic: Causes and trends. Deep-Sea Research II 57, 1346-1361.

Lauermann, L., Kaufmann, R.S. 1998. Deep-sea epibenthic echinoderms and a temporally varying food supply: results from a one year time series in the N.E. Pacific. Deep-Sea Research II 45, 817-842.

Longhurst, A., 2007. Ecological Geography of the Sea, Elsevier, USA.

Martynov, A. (2010). Reassessment of the classification of the Ophiuroidea (Echinodermata), based on morphological characters. I. General character evaluation and delineation of the families Ophiomyxidae and Ophiacanthidae. Zootaxa 2697, 1154.

Pearson, M., Gage, J.D., 1984. Diets of some deep-sea brittle stars in the Rockall Trough. Marine Biology 82, 247-258.

Pollard, R.T., Sanders, R.J., Lucas, M.I., Statham, P., 2007a. The Crozet natural iron bloom and export experiment (CROZEX). Deep-Sea Research II 54, 1905-1914.

Pollard, R.T., Venables, H., Read, J.F., Allen, J.T., 2007b. Large-scale circulation around the Crozet Plateau controls an annual phytoplankton bloom in the Crozet Basin. Deep-Sea Research II 54, 1915-1929.

Pollard, R.T., Salter, I., Sanders, R.J., Lucas, M.I., Moore, C.M., et al. 2009. Southern Ocean deep-water carbon export enhanced by natural iron fertilization. Nature 457, 577-581.

Ruhl, H.A. 2007. Abundance and size distribution dynamics of abyssal epibenthic megafauna in the northeast Pacific. Ecology $88,1250-1262$.

Salter, I. Kemp, A.E.S., Moore, C.M., Lampitt, R.S., Wolff, G.A., Holtvoeth, J., 2012. Diatom resting spore ecology drives enhanced carbon export from a naturally iron-fertilized bloom in the Southern Ocean. Global Biogeochemical Cycles 26, GB1014, doi:10.1029/2010GB003977.

Schoener, A. 1972. Fecundity and possible mode of development of some deep-sea ophiuroids. Limnology and Oceanography 17 (2), 193-199.

Siegal, S., Castellan, N.J., 1988. Nonparametric Statistics for the Behavioural Sciences. Second Edition. McGraw-Hill, New York. 399pp.

Smith, C.R., De Leo, F.C., Bernardino, A.F., Sweetman, A., Martinez, P., 2008. Abyssal food limitation, ecosystem structure and climate change. Trends in Ecology and Evolution 23, 518-528.

Smith, K.L., Ruhl, H., Bett, B.J., Billett, D.S.M., Lampitt, R.S. \& Kaufmann, R.S., 2009. Climate, carbon cycling and deep-ocean ecosystems. Proceedings of the National Academy of Sciences 106 (46), 19211-19218.

Sokal, R.R., Rolhf, F.J., 1995. Biometry: The Principals and Practices of Statistics in Biological Research. $3^{\text {rd }}$ Edition. W.H. Freeman and Company, New York.

Sokolova, M.N. 2000. Feeding and trophic structure of the deep-sea macrobenthos. Smithsonian Institution Libraries, Washington D.C. $264 \mathrm{pp}$.

Soto, E., Paterson, G.L.J., Billett, D.S.M., Hawkins, L.E., Galéron, J., Sibuet, M., 2010. Temporal variability in polychaete assemblages of the abyssal NE Atlantic Ocean. Deep-Sea Research II 57 (15), 1396-1405.

Sumida, P.Y.G., Tyler, P.A., Lampitt, R.S., Gage, J.D., 2000.
Reproduction, dispersal and settlement of the bathyal ophiuroid Ophiocten gracilis in the NE Atlantic. Marine Biology 137, $623-$ 630.

Tyler, P.A., 1980. Deep-sea ophiuroids. Oceanography and Marine Biology: An Annual Review 18, 125-153.

Tyler, P.A., 1988. Seasonality in the deep sea. Oceanography and Marine Biology: An Annual Review 26, 227-258

Tyler, P.A., 1996 Conditions for the existence of life at the deep-sea floor: an update. Oceanography and Marine Biology: An Annual Review 33, 221-244.

Tyler, P.A., Gage, J.D., 1980. Reproduction and growth in the deep-sea brittle star Ophiura ljungmani (Lyman). Oceanologica Acta 3, 177-185.

Tyler, P.A., Gage, J.D., 1982. The reproductive biology of Ophiacantha bidentata (Echinodermata: Ophiuroidea) from the Rockall Trough. Journal of the Marine Biological Association of the United Kingdom 62, 45-55.

Tyler, P.A., Grant, A., Pain, S.L., Gage, J.D., 1982. Is annual reproduction in deep-sea echinoderms a response to variability in their environment? Nature 300, 747-750

Venables, H., Pollard, R.T., Popova, E.E., 2007. Physical conditions controlling the development of a regular phytoplankton bloom north of the Crozet Plateau, Southern Ocean. Deep-Sea Research II 54, 1949-1965.

Warner, G.F. 1982. Food and feeding mechanisms: Ophiuroidea. In: Echinoderm Nutrition. Jangoux, M., Lawrence, J.M. (Eds). A.A. Balkema, Rotterdam. pp 161-181.

Wei, C-L., Rowe, G.T., Escobar-Briones, E., Boetius, A., Soltwedel, T., ; Caley, M.J., et al., 2010. Global patterns and predictions of seafloor biomass using Random Forests. PLoS One 5 (12), e15323 http://dx.plos.org/10.1371/journal.pone.0015323.

Wigham, B.D., Hudson, I.R., Billett, D.S.M., Wolff, G.A., 2003. Is long-term change in the abyssal Northeast Atlantic driven by qualitative changes in export flux? Evidence from selective feeding in deep-sea holothurians. Progress in Oceanography 59, 409-441.

Wolff, G.A. et al. 2006. Benthic Crozet - Surface water productivity, variability in export flux and deep-sea diversity - how are they linked? Cruise Report RRS Discovery Cruise 300. British Oceanography Data Centre.

Wolff, G.A., Billett, D.S.M., Bett, B.J., Holtvoeth, J., FitzGeorgeBalfour, T., et al., 2011. The effects of natural iron fertilisation on deep-sea ecology. PLoS One 6 (6), 1-9. e20697 http://dx.plos.org/10.1371/journal.pone.0020697.

Young, C.M., 2003. Reproduction, development and life-history traits. In: Ecosystems of the World. Vol 28. Ecosystems of the Deep Ocean. Tyler, P.A. (Ed). pp 381-426. 
PREPRINT OF: Billett et al. (2013) Ophiuroid reproductive ecology in different productivity regimes

Table 1 Sampling station location, depth and date of sampling. Ophiuroid samples used for histological studies were collected from stations $15773 \# 17$ and $15774 \# 5$.

\begin{tabular}{|llllll|}
\hline Site & Station No. & Latitude, $\mathbf{S}$ & Longitude, E & Depth, $\mathbf{m}$ & Date \\
\hline$+\mathrm{Fe}$ & $15773 \# 8$ & $45^{\circ} 43.06^{\prime}$ & $56^{\circ} 32.16^{\prime}$ & $4258-4290$ & 12 Dec 2005 \\
$+\mathrm{Fe}$ & $15773 \# 17$ & $45^{\circ} 43.47^{\prime}$ & $56^{\circ} 36.66^{\prime}$ & $4301-4283$ & 15 Dec 2005 \\
$+\mathrm{Fe}$ & $15773 \# 23$ & $45^{\circ} 40.05^{\prime}$ & $56^{\circ} 35.27^{\prime}$ & $4269-4275$ & 16 Dec 2005 \\
$+\mathrm{Fe}$ & $15773 \# 32$ & $45^{\circ} 40.45^{\prime}$ & $56^{\circ} 33.70^{\prime}$ & $4267-4270$ & 20 Dec 2005 \\
$\mathrm{HNLC}$ & $15775 \# 4$ & $48^{\circ} 56.21^{\prime}$ & $51^{\circ} 03.90^{\prime}$ & $4182-4195$ & 27 Dec 2005 \\
$\mathrm{HNLC}$ & $15775 \# 13$ & $49^{\circ} 01.15^{\prime}$ & $51^{\circ} 04.52^{\prime}$ & $4187-4191$ & $29 \operatorname{Dec} 2005$ \\
\hline
\end{tabular}


Table 2. Data on abundance (individuals per hectare) andf biomass ( $\mathrm{g}$ preserved wet weight per hectare) of each ophiuroid species and mean values and standard deviations for + Fe and HNLC sites

\section{Density (ind ha-1)}

$\begin{array}{rcccc}\text { Station } & 15773 \# 8 & 15773 \# 17 & 15773 \# 23 & 15773 \# 32 \\ \text { Area fished (hectares) } & 2.532 & 6.833 & 10.751 & 4.714 \\ \text { Species } & & & & \end{array}$

Amphioplus antarctica

Amphioplus daleus

Amphiura studeri (antarctica)

Ophiernus quadrispinus

Ophiolepis ?scissa

Ophiotrema tertium

Ophiuria irrorata loven

Ophiura lienosa

Ophiacantha cosmica

$\begin{array}{rr}0 & 0 \\ 148.10 & 99.08 \\ 27.25 & 13.46 \\ 10.66 & 12.59 \\ 0 & 2.93 \\ 0 & 0.15 \\ 30.81 & 49.17 \\ 277.25 & 146.06 \\ 11.45 & 5.56 \\ & \\ 505.53 & 328.99\end{array}$

\section{Biomass (g ha-1)}

Species

Amphioplus antarctica

Amphioplus daleus

Amphiura studeri (antarctica)

Ophiernus quadrispinus

Ophiolepis ?scissa

Ophiotrema tertium

Ophiuria irrorata loveni

Ophiura lienosa

Ophiacantha cosmica

$\begin{array}{rr}0 & 40.94 \\ 62.88 & 289.78 \\ 11.72 & 0 \\ 5.21 & 0 \\ 0 & 0 \\ 0 & 0 \\ 28.18 & 67.88 \\ 69.67 & 506.15 \\ 4.09 & 15.49\end{array}$

$181.75 \quad 920.24$
$+\mathrm{Fe}$
std dev

$10.24 \quad 2$

$\begin{array}{rr}10.24 & 2 \\ 149.96 & 31\end{array}$

13.113

$\begin{array}{ll}7.11 & 1\end{array}$

0.730

$0.04 \quad 0$

44.019

$249.78 \quad 52$

484.13
20.47

99.54

11.16

5.68

1.46

0.07

18.45

191.21

5.29

319.45

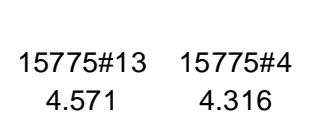

4.571

$\begin{array}{rr}0 & 0 \\ 37.19 & 38.69 \\ 0 & 0 \\ 0 & 3.94 \\ 0 & 1.16 \\ 31.72 & 116.77 \\ 11.38 & 30.35 \\ 147.01 & 179.10 \\ 19.25 & 47.73\end{array}$

246.55

417.75
HNLC

mean

$\begin{array}{rrr}0 & 0 & 0\end{array}$

$\begin{array}{rr}37.94 & 11 \\ 0 & 0\end{array}$

$1.97 \quad 1$

$0.58 \quad 0$

$74.25 \quad 22$

$20.86 \quad 6$

$163.06 \quad 49$

$33.49 \quad 10$

332.15

1.06
0

2.79

0.82

60.14

13.42

22.69

20.14

121.05

$\begin{array}{rrrrrcr}0 & 0 & 0 & 8.82 & 2.21 & 1 & 4.41 \\ 40.19 & 30.37 & 18.81 & 69.82 & 39.80 & 25 & 21.84 \\ 5.09 & 2.90 & 2.38 & 0 & 2.59 & 2 & 2.09 \\ 5.61 & 5.69 & 2.28 & 0 & 3.40 & 2 & 2.77 \\ 0 & 0.34 & 0 & 0 & 0.08 & 0 & 0.17 \\ 0 & 0.01 & 0 & 0 & 0.00 & 0 & 0.01 \\ 29.86 & 47.08 & 24.19 & 64.35 & 41.37 & 26 & 18.15 \\ 92.69 & 40.42 & 17.50 & 121.20 & 67.95 & 42 & 47.44 \\ 4.03 & 3.53 & 2.67 & 8.40 & 4.66 & 3 & 2.56 \\ 177.47 & 130.34 & 67.83 & 272.59 & 162.06 & & 86.29\end{array}$

$\begin{array}{rr}0 & 0 \\ 6.77 & 6.46 \\ 0 & 0 \\ 0 & 2.37 \\ 0 & 0.06 \\ 3.65 & 15.02 \\ 10.66 & 28.71 \\ 57.68 & 71.57 \\ 7.66 & 30.63 \\ & \\ 86.43 & 154.82\end{array}$

$\begin{array}{rr}0 & 0 \\ 6.62 & 5 \\ 0 & 0 \\ 1.19 & 1 \\ 0.03 & 0 \\ 9.33 & 8 \\ 19.69 & 16 \\ 64.62 & 54 \\ 19.15 & 16 \\ & \\ 120.63 & \end{array}$

0

0.22

0
1.68

0.04

8.03

12.77
9.82

16.24

48.36 

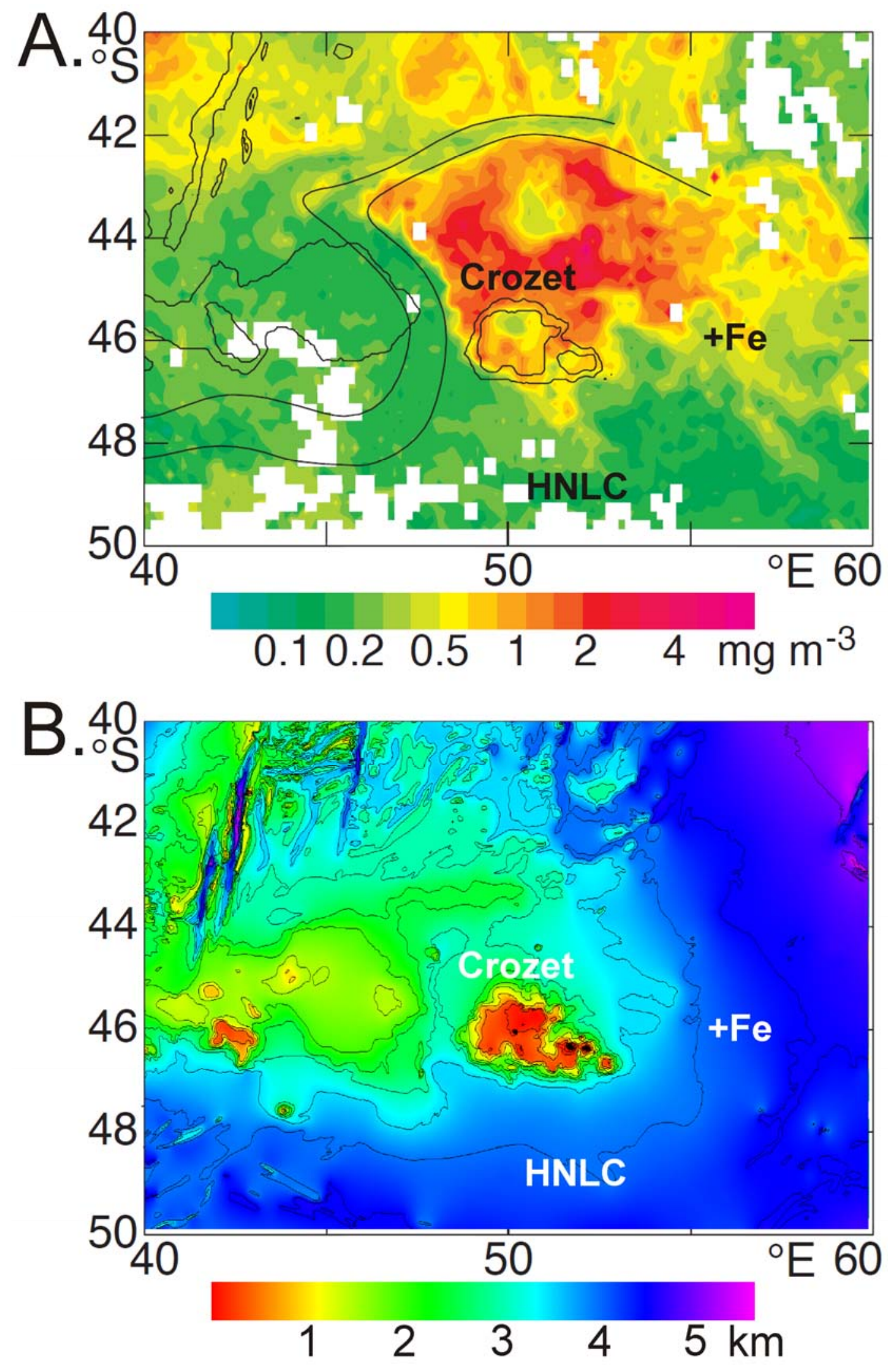

Figure 1. Sampling locations of the $+\mathrm{Fe}$ and HNLC sites. A. SeaWiFS chlorophyll image October 1998 showing the distribution of the austral phytoplankton spring bloom restricted to the north and east of the Crozet Plateau (Pollard et al. 2007a); B. Bathymetric chart showing abyssal locations of the $+\mathrm{Fe}$ and HNLC sites with similar characteristics and no topographic boundary between them. 
PREPRINT OF: Billett et al. (2013) Ophiuroid reproductive ecology in different productivity regimes

A.

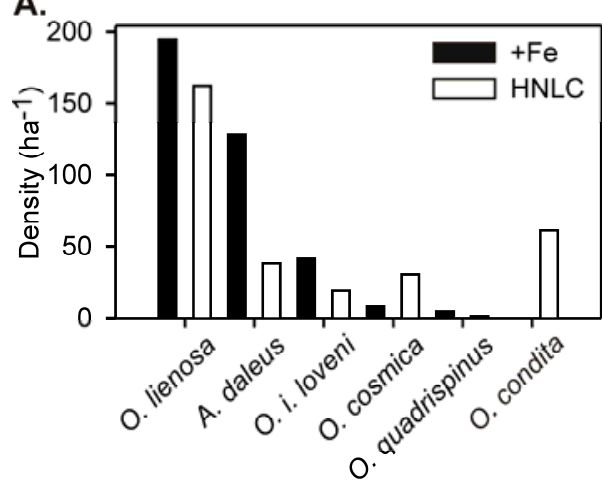

B.

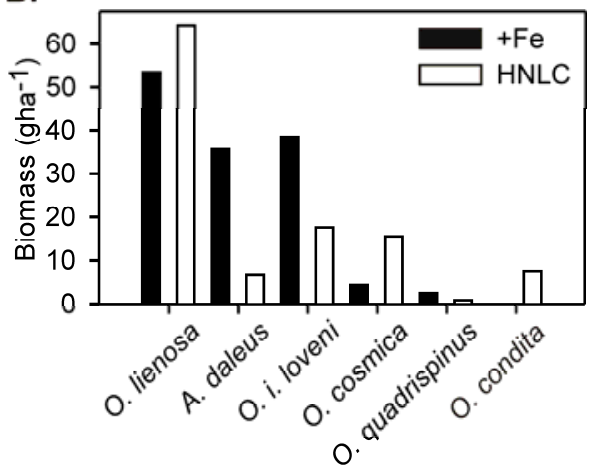

Figure 2. A. The density of the six most abundant ophiuroid species at the Crozet $+F e$ and HNLC sites; B. The preserved wet weight biomass of the six principal ophiuroid species at the Crozet $+\mathrm{Fe}$ and HNLC sites.
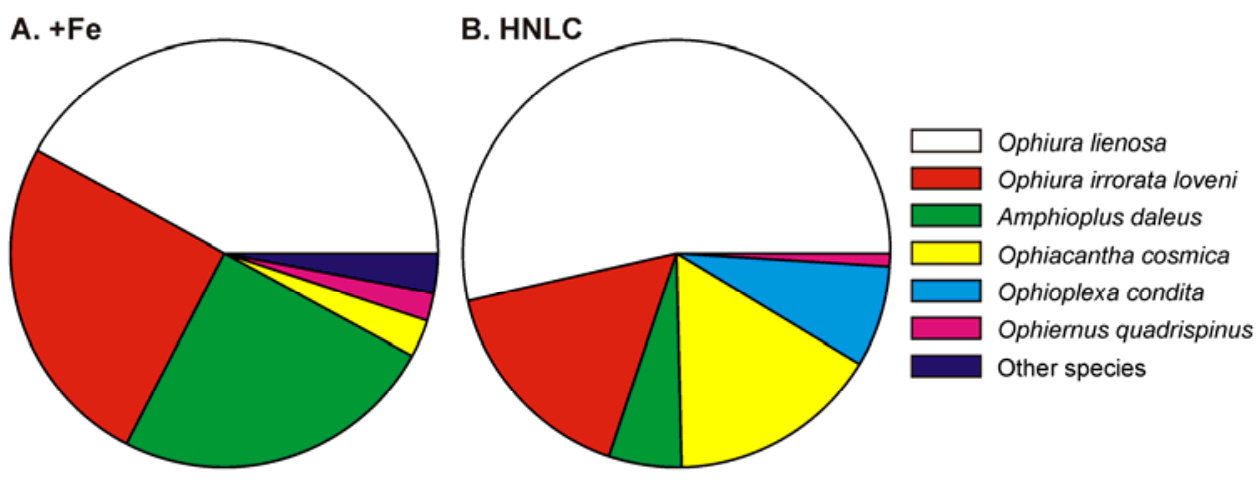

Figure 3. A. The relative abundance of the dominant ophiuroid species at Crozet, showing differences in the assemblages at $\mathrm{A} .+\mathrm{Fe}$ natural iron fertilisation site; $\mathrm{B}$. HNLC site.
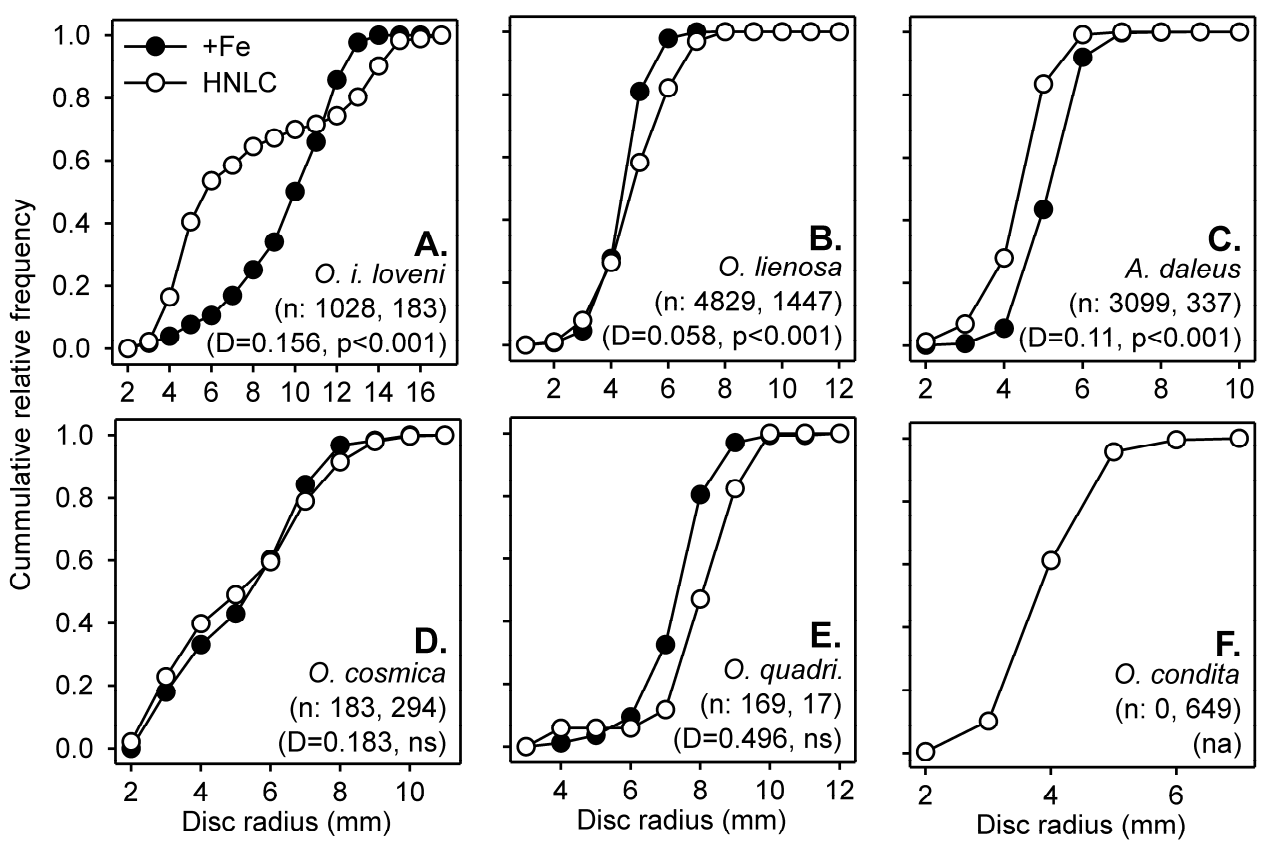

Figure 4. Population size distributions as measured by disc radius in millimetres. Filled circles, + Fe site. Open circles, HNLC site. A. Ophiura irrorata loveni; B. Ophiura lienosa; C. Amphioplus daleus; D. Ophiacantha cosmica; E. Ophiernus quadrispinus; F. Ophioplexa condita. 
PREPRINT OF: Billett et al. (2013) Ophiuroid reproductive ecology in different productivity regimes
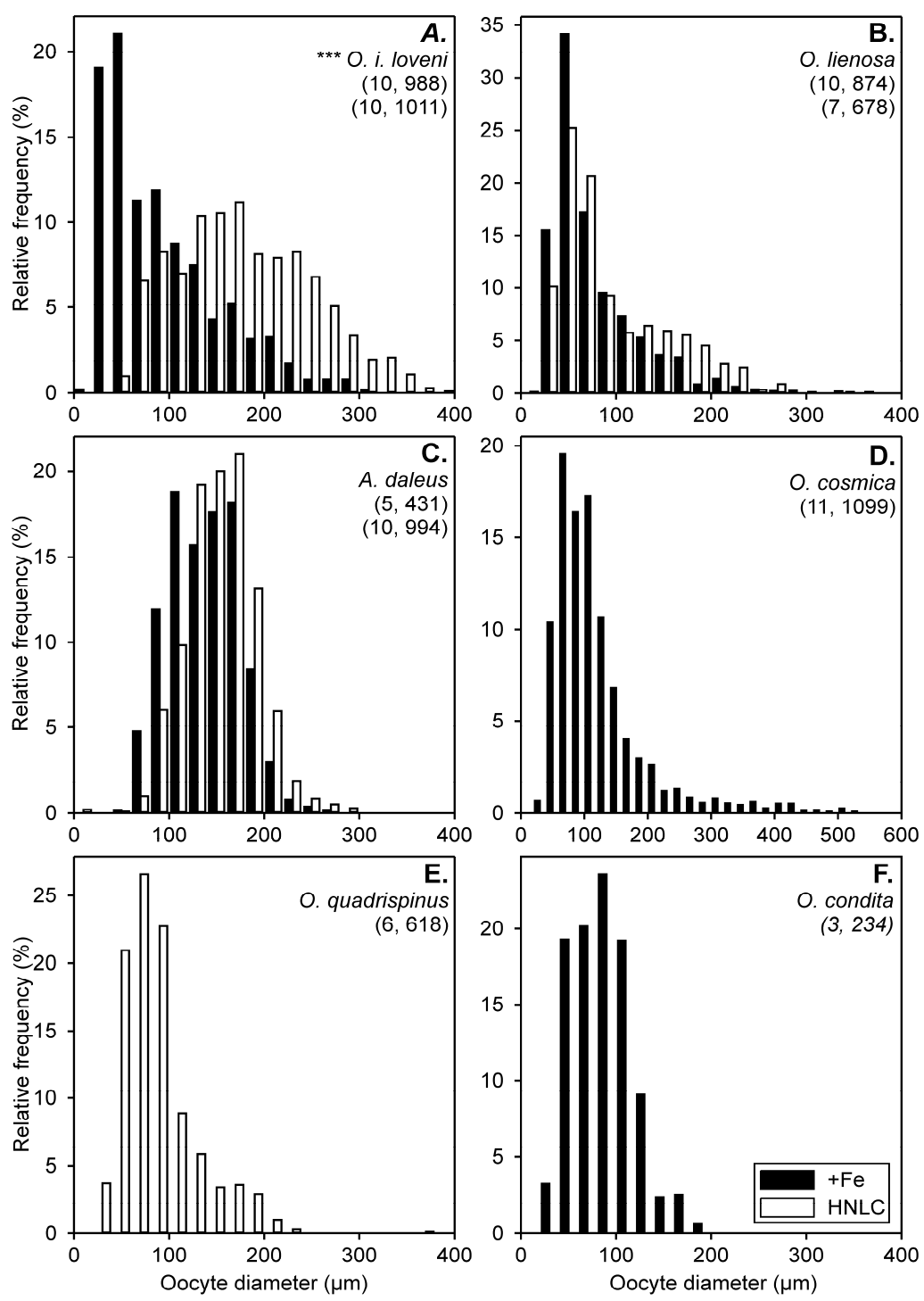

Figure 5. Oocyte size frequency distributions of oocyte diameters as measured in microns and presented in 20 micron intervals. Filled histograms, +Fe site. Open histograms, HNLC site. A. Ophiura irrorata loveni; B. Ophiura lienosa; C. Amphioplus daleus; D. Ophiacantha cosmica; E. Ophiernus quadrispinus; F. Ophioplexa condita.

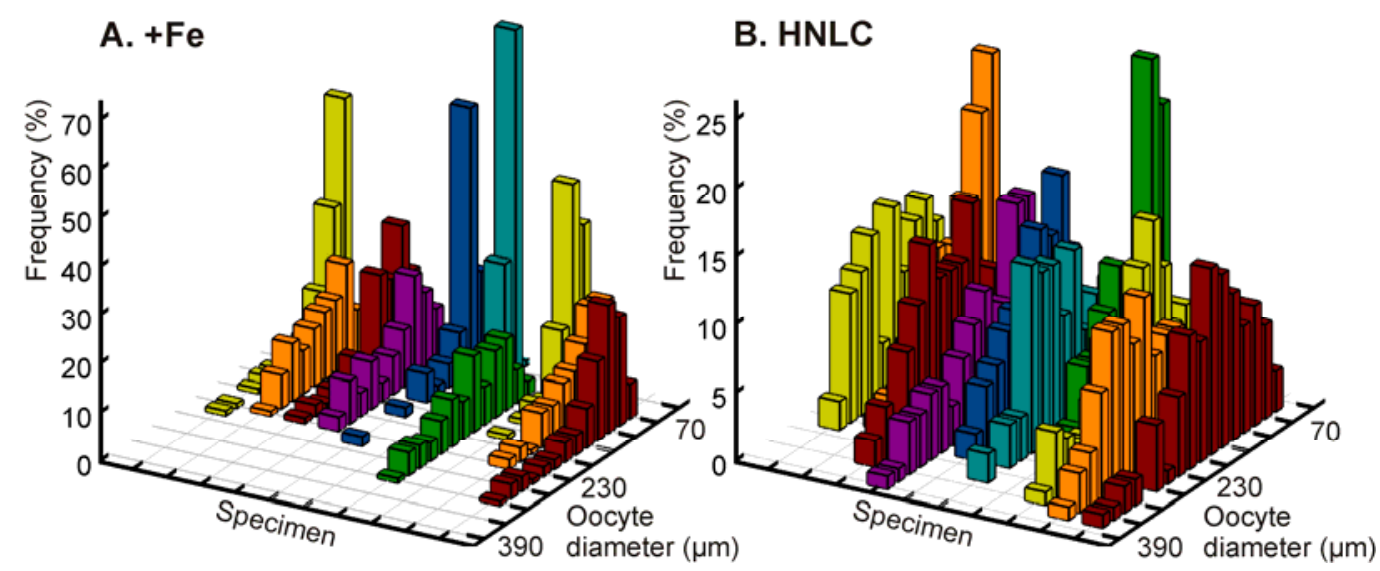

Figure 6. Oocyte size distributions for Ophiura irrorata loveni of 10 individuals measured at each site showing the variation between individuals, and between sites. A. +Fe; B. HNLC site. Note different frequency scales. 